\title{
In vitro and In vivo Evaluation of Antioxidant Properties of Moringa Oleifera Ethanolic Leaves Extract and Effect on Serum Lipid Indices in Rat
}

Henrietta Ogbunugafor ${ }^{1}$, Miriam Igwo-Ezikpe², Innocent Igwilo', Nwaorah Ozumba ${ }^{1}$, Sunday Adenekan², Chidozie Ugochukwu ${ }^{1}$, Obumuneme Onyekwelu ${ }^{1}$, Anthony Ekechi ${ }^{3}$

${ }^{1}$ Nnamdi Azikiwe University, Faculty of Biosciences, Applied Biochemistry Department, Akwa, Anambra State Nigeria; ${ }^{2}$ University of Lagos, College of Medicine, Biochemistry Department, Idiaraba, Lagos state, Nigeria; ${ }^{3}$ Federal University of Technology, Biochemsitry Department, Owerri, Imo State, Nigeria

\begin{abstract}
Citation: Ogbunugafor $\mathrm{H}$, Igwo-Ezikpe M, Igwilo I, Ozumba N, Adenekan S, Ugochukwu C, Onyekwelu O, Ekechi A. In vitro and In vivo Evaluation of Antioxidant Properties of Moringa Oleifera Ethanolic Leaves Extract and Effect on Oleifera Ethanolic Leaves Extract and Effect on Serum Lipid Indices in Rat. Maced J Med Sci. 2012 Dec 15; 5(4):397-403. http://dx.doi.org/ 10.3889/MJMS.1857-5773.2012.0240.

Key words: Moringa oleifera Lam; free radicals; Antioxidants; Lipid indices; serum.

Correspondence: Dr. Miriam IgwoEzikpe.University of Lagos, College of Medicine, Department of Biochemistry, Faculty of Basic Medical Sciences, P.M.B. 12003, Lagos, Nigeria. E-mail: mimiigwo@yahoo.co.uk

Received: 21-Apr-2012; Revised: 01-Sep-2012; Accepted:09-Oct-2012; Online first:10-Nov-2012

Copyright: (c) 2012 Ogbunugafor H. This is an open-access article distributed under the terms of the Creative Commons Attribution permits unrestricted use, distribuse, which permits unestricted use, distribution, and reproduction in any medium, provided the origin author and source are credited.

Competing Interests: The author have declared that no competing interests exist.
\end{abstract}

\section{Abstract}

Background: The pathogenesis of reactive oxygen species (ROS) linked chronic diseases such as hypertension, rheumatoid arthritis, and diabetes has warranted the intensive search for plants with antioxidant properties.

Aim: The in vitro and in vivo antioxidant properties of ethanolic leaves extract of Moringa oleifera Lam (Moringaceae) and its effect on lipid indices in male albino rats were investigated.

Material and Methods: The in vitro antioxidant properties of the extract were determined; while the in vivo studies involved three groups of five male rats orally administered with extract $[1 \mathrm{~mL}(200 \mathrm{mg} / \mathrm{kg}$ $\left.{ }^{1}\right)$ ], alpha-tocopherol [ $\left.1 \mathrm{~mL}\left(500 \mathrm{mg} / \mathrm{kg}^{-1}\right)\right]$ and $1 \mathrm{~mL} 5 \%$ Tween 20 (control) respectively for 21 days. The effects on enzymatic antioxidants and lipid indices were evaluated.

Results: Hydrogen peroxide scavenging ability of the extract was significantly $(p<0.05)$ higher than that of alpha-tocopherol. Superoxide dismutase and catalase activities were increased, while triacylglycerides and very low density lipoprotein were significantly $(p<0.05)$ lowered by the extract. Malonaldehyde levels were not significantly $(p<0.05)$ different in the extract, alpha-tocopherol and control treated groups.

Conclusion: The extract had appreciable phenol content and exhibited in vitro antioxidant properties. The extract also had modulating effects on enzymatic antioxidants, showed lipid-lowering ability and caused changes in types of lipoproteins found in serum.

\section{Introduction}

Recently, the incidences of chronic diseases have been on the increase and these are probably due to several factors which include changes in lifestyle, diet, and greater consumption of processed foods and drinks. It is widely reported that free radicals play an important role in the pathogenesis of chronic diseases: such as cancer, rheumatoid arthritis, and cardiovascular diseases such as hypertension $[1,2]$. This is because major cellular components which include lipids (peroxidation of unsaturated fatty acids in membranes), proteins (denaturation), carbohydrates and nucleic acids are susceptible to damage by free radicals. Free radicals are generated as byproducts of normal aerobic metabolism as well as metabolic reactions with drugs, toxins and alcohol.

Polyphenols constitute the largest class of phytochemicals and dietary polyphenols have been 
shown to play important roles in human health. They are natural antioxidants present in plants, conferring protection against free radicals when consumed, thus are important in maintaining good health $[3,4]$. Antioxidants are powerful metal chelators and operate cooperatively, employing a series of redox reactions to detoxify free radicals [5]. Recent research strongly support high intake of fruits, vegetables and whole grains, which are rich in polyphenols, as a link to lowered risks of many chronic and degenerative diseases [2].

Furthermore, the role of serum lipoprotein disturbances and abnormal lipid metabolism characterized by hyperlipidaemia as an etiological factor in the development of coronary heart diseases has also been reported [1]. Therefore, evaluation of plants for their antioxidant and lipid lowering capacity is a good approach to finding safer and cheaper ways of managing chronic diseases.

Moringa oleifera Lam. (Moringaceae) is native to India, Africa and the Middle East. It has long been identified by some traditional herbalists to cure many diseases, and has been used as food and nutritional supplement [6]. However, it is only recently that modern scientists began to corroborate its benefits. The plant has been shown to have little side effects [7, 8]; and has been given to malnourished babies in some parts of Africa [9].

Nevertheless, the mode of action of its medicinal properties has not been completely elucidated. Therefore, the in vitro and in vivo evaluation of the effect of $M$. oleifera leaves extract on antioxidant parameters and lipid indices are important in order for the plant to serve as a suitable alternative to synthetic drugs in the management of chronic diseases. The plant's product ability to elicit in vivo antioxidant activity could point to the most probable way the extract achieves its pharmacological activity.

The present study seeks to assess the in vitro antioxidant capacity of $M$. oleifera ethanolic leaves extract in order to establish the antioxidant potentials of the plant and determine the activities of serum superoxide dismutase and catalase in order to ascertain the effect of the extract on enzymatic antioxidants. In addition, the extract's effect on lipid peroxidation was investigated to enable an assessment of its membrane deterioration effect likewise serum lipid profile was evaluated in order to determine the extract's effect on lipoproteins distribution.

\section{Materials and Methods}

\section{Extract preparation}

The leaves of $M$. oleifera were collected in Nimo, Anambra state, Nigeria. They were identified and authenticated at the Department of Botany, Nnamdi Azikiwe University herbarium (Herbarium no NAUH 48). The collected leaves of the plant were air dried under shade for 14 days and pulverized. The pulverized leaves $(400 \mathrm{~g})$ were extracted by maceration with $1 \mathrm{~L}$ of $80 \%$ ethanol for $24 \mathrm{~h}$ at $4{ }^{\circ} \mathrm{C}$. The $M$. oleifera ethanolic leaves extract solution was filtered through Whatman filter paper No. 1 and freeze dried (FT33-Armfield, England). The extract was weighed, percent yield calculated, and stored in an air-tight container at $4{ }^{\circ} \mathrm{C}$.

\section{In vitro Studies}

The in vitro antioxidant capability of $M$. oleifera ethanolic leaves extract was evaluated. The parameters determined include total phenol content, total flavonoid content, total antioxidant capacity, reducing power and hydrogen peroxide scavenging ability. Vitamin $C$ was used as a reference antioxidant due to its role as scavenger of free radicals through electron transfer. Absorbance was measured spectrophotometrically (Amershan Biosciences Ultraspec. 3100 Pro UV visible; UK).

\section{Estimation of total phenol content}

The total phenol content of the ethanolic extract sample was determined using Folin-Ciocalteu reagent according to the modified method of Khanahmadi et al., [10]. The amount of total phenol content in the extract solution was determined from gallic acid calibration curve and was expressed as $\mathrm{mg}$ of Gallic Acid Equivalent per gram sample $\left(\mathrm{mg} \mathrm{GAE} \mathrm{g}^{-1}\right)$.

\section{Estimation of total flavonoid content}

The total flavonoid content of the ethanolic extract sample was determined by aluminum trichloride colorimetric method using rutin as standard [11]. The method was based on formation of a flavonoid-aluminum complex. The amount of flavonoid was calculated from rutin calibration curve, results expressed as mg of Rutin Equivalent per gram of sample ( $\mathrm{mg} \mathrm{RE} \mathrm{g}^{-1}$ ).

\section{Total antioxidant capacity}

The total antioxidant capacity was evaluated by phosphomolybdenum method as described by Nabasree 
and Bratatti [12]. The assay was based on the reduction of $\mathrm{Mo}(\mathrm{VI})$ to Mo $(\mathrm{V})$ by the sample and subsequent formation of a green phosphate/Mo $(\mathrm{V})$ complex at acidic $\mathrm{pH}$. Extract solution in ethanol $\left(0.3 \mathrm{~mL} ; 100 \mu \mathrm{g} \mathrm{mL}^{-1}\right)$ was mixed with reagent solution ( $3 \mathrm{~mL} ; 0.6 \mathrm{M}$ sulphuric acid, $28 \mathrm{mM}$ sodium phosphate and $4 \mathrm{mM}$ ammonium molybdate). A blank composed of $3 \mathrm{~mL}$ of reagent solution and methanol was also prepared. All tubes were capped and incubated in boiling water bath at $95^{\circ} \mathrm{C}$ for 90 min. Absorbance of samples were read against blank at $695 \mathrm{~nm}$. The antioxidant capacities of samples were expressed as mg Ascorbic Acid Equivalent per gram of sample (mg AAE g-1).

\section{Determination of reducing power}

The reducing power ability of the extract was determined using the method of Adesegun et al., [13] by mixing $2.5 \mathrm{~mL}$ of extract solution of various concentrations $(25,50,75,100,150,200,250,300,400,600,800 \mu \mathrm{g}$ $\mathrm{mL}^{-1}$ ), with $2.5 \mathrm{~mL}$ of $1 \%$ potassium ferricyanide and incubated at $50{ }^{\circ} \mathrm{C}$ for $20 \mathrm{~min}$. Trichloroacetic acid (2.5 $\mathrm{mL}, 10 \%)$ was added and centrifuged (1000 $\times \mathrm{g}, 10 \mathrm{~min})$. The supernatant $(2.5 \mathrm{~mL})$ was mixed with equal volume of distilled water and ferric chloride $(0.5 \mathrm{~mL}, 0.1 \%)$. The absorbance was measured at $700 \mathrm{~nm}$ against a reagent blank and the procedure was repeated using ascorbic acid.

\section{Hydrogen peroxide scavenging ability}

The decomposition of hydrogen peroxide by the extract was estimated by the method of Oktay et al., [14]. Hydrogen peroxide solution (2 $\mathrm{mM}$ ) was prepared with standard phosphate buffer ( $\mathrm{pH} 7.4)$. Sample $(25,50,75$, $100,150,200,250,300,400,600,800 \mu \mathrm{g} \mathrm{mL}{ }^{-1}$ ) in distilled water was added to hydrogen peroxide solution $(0.6 \mathrm{~mL})$. Absorbance of hydrogen peroxide at $230 \mathrm{~nm}$ was determined spectrophotometrically after $10 \mathrm{~min}$ against a blank solution containing phosphate buffer without hydrogen peroxide. The percentage scavenging potential of hydrogen peroxide of the plant extract and standard control (alpha-tocopherol) were determined.

\section{In vivo Studies}

Test animals: Fifteen male normotensive rats used for this experiment were purchased from the rat colony at the Department of Veterinary Parasitology and Entomology, University of Nigeria, Nsukka. The animals were housed in standard rat cages to minimize their discomfort and were fed with commercial livestock feed (Topfeeds Ltd, Asaba, Delta State, Nigeria) and water ad libitum. The feed was composed of crude protein, 18 $\%$; fat, $6 \%$; crude fiber, $5.00 \mathrm{kcal} \mathrm{kg}^{-1}$; calcium, $1.00 \mathrm{mg}$; available phosphorous, $0.40 \mathrm{mg}$; lysine, $0.85 \mathrm{mg}$; methionine, $0.35 \mathrm{mg}$; salt, (minute); metabolizable energy, $2900 \mathrm{kcal} \mathrm{kg-}^{1}$. The animals were acclimatized for 14 days and handled in accordance with the guidelines of Institute for Laboratory Animal Research (ILAR).

Chemicals and Equipment: Hydrogen peroxide $\left(\mathrm{H}_{2} \mathrm{O}_{2}\right)$, Epinephrine $\left(\mathrm{C}_{9} \mathrm{H}_{13} \mathrm{O}_{3} \mathrm{~N}\right)$, Tween 20 and alphatocopherol (vitamin E) were purchased from SigmaAldrich, Germany. All other chemicals used, including solvents, were of analytical grade. UV-Visible spectrophotometer (Amershan Biosciences Ultraspec. 3100 Pro; UK) was used for spectrophotometric measurements.

Animal treatment: Rats weighing between 180$220 \mathrm{~g}$ were sorted into 3 groups of 5 rats each. The respective groups were orally administered with $M$. oleifera ethanolic leaves extract [1 mL (200 mg kg-1)], alpha-tocopherol [1 mL (500 $\left.\left.\mathrm{mg} \mathrm{kg}^{-1}\right)\right]$, and $1 \mathrm{~mL}$ of $5 \%$ Tween 20 (control) for 21 days. Alpha-tocopherol which is a lipid-soluble antioxidant that plays a role in protecting membranes from oxidative damage [16] was used as reference antioxidant.

The animals were fasted overnight and anaesthetized with chloroform. The animals were sacrificed by severing the jugular vein with a surgical blade. Blood was allowed to flow freely and was collected in plain bottles. The blood was allowed to clot and then centrifuged at $1500 \times g$ for 5 min after which the clear supernatant (serum) was separated from pellet and used for enzymes assay.

Determination of Superoxide dismutase activity (SOD): The method of Sun and Sigma as described by Ogbunugafor et al., [17] was adopted. The reaction mixture $(3 \mathrm{~mL})$ contained $2.95 \mathrm{~mL}$ sodium carbonate buffer $(0.05 \mathrm{M}, \mathrm{pH} 10.2), 0.02 \mathrm{~mL}$ of serum and $0.03 \mathrm{~mL}$ of epinephrine in $0.005 \mathrm{~N} \mathrm{HCL}$ used to initiate the reaction. The reference cuvette contained $2.95 \mathrm{~mL}$ buffer, $0.03 \mathrm{~mL}$ of substrate (epinephrine) and $0.02 \mathrm{~mL}$ of water. An extinction coefficient for epinephrine at $480 \mathrm{~nm}$ of $4020 \mathrm{M}^{-1} \mathrm{~cm}^{-1}$ was used in calculating activity.

Determination of Catalase activity (CAT): Serum catalase activity was determined according to the method of Beers and Sizer as described by Usoh et al., [18]. The reaction mixture $(3 \mathrm{~mL})$ contained $0.1 \mathrm{~mL}$ of serum in phosphate buffer $(50 \mathrm{mM}, \mathrm{pH} 7.0)$ and $2.9 \mathrm{~mL}$ of $30 \mathrm{mM} \mathrm{H}_{2} \mathrm{O}_{2}$ in phosphate buffer $\mathrm{pH}$ 7.0. An extinction 
coefficient for $\mathrm{H}_{2} \mathrm{O}_{2}$ at $240 \mathrm{~nm}$ of $40.0 \mathrm{M}^{-1} \mathrm{~cm}^{-1}$ as described by Aebi, [19] was used for the calculation.

\section{Determination of lipid peroxidation index} (LPO): Lipid peroxidation was estimated based on the formation of TBARS (thiobarbituric acid reactive substances) as an index of lipid peroxidation according to the method of Niehaus and Samuelson as described by Usoh et al., [20]. Malonaldehyde (MDA) which is an index of LPO was calculated with extinction coefficient of $1.5 \times 10^{5} \mathrm{M}^{-1} \mathrm{~cm}^{-1}$.

Determination of lipid concentration: The concentration of total cholesterol (TC), low density lipoprotein (LDL-cholesterol), high density lipoprotein (HDL-cholesterol), very low density lipoprotein (LDL) and triacylglycerides (TAG) was estimated in rats' serum after administration of the $M$. oleifera ethanolic leaves extract, alpha-tocopherol and control respectively. The TC, HDL and TAG in serum were determined enzymatically using commercially available test kits (Boehringer, Mannheim, Germany). LDL-cholesterol was calculated by the Friedewald formula:

$$
\begin{gathered}
\text { LDL cholesterol }=\text { total cholesterol }(\mathrm{TC})-\mathrm{HDL} \\
\text { cholesterol }- \text { triacyglycerides } \div 5 \\
\text { VLDL }=\text { Triacylglycerides } \div 5 \text { Tietz, }[19] .
\end{gathered}
$$

\section{Statistical analysis}

Results were expressed as Mean \pm SEM. Statistical significant difference $(P<0.05)$ was determined using student's t-test. All data were analyzed using Statistical Package for the Social Science 15.0 for windows (SPSS 15.0).

\section{Results}

\section{Plant extraction}

The percentage yield of $M$. oleifera ethanolic leaves extract (w/w) was $18.88 \%$.

\section{In vitro Antioxidant determination}

Total phenol content of the extract was $7.10 \pm$ $0.02\left(\mathrm{mg} \mathrm{GAE} \mathrm{g}^{-1}\right)$, total flavonoid was $98.20 \pm 0.60$ (mg $\mathrm{RE} \mathrm{g}^{-1}$ ) while total antioxidant capacity was $35.20 \pm 0.07$ $\left(\mathrm{mg} \mathrm{AAE} \mathrm{g}^{-1}\right)$. The extract at varying concentrations (25 - $800 \mu \mathrm{g} \mathrm{mL}^{-1}$ ) was observed to have reducing power potential.

There was no significant $(p<0.05)$ difference in

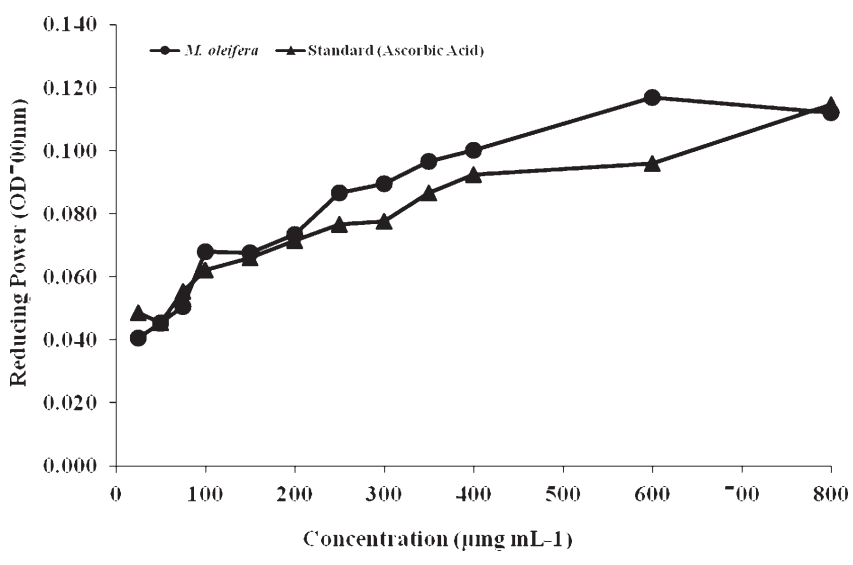

Figure 1: Reducing power potential of Moringa oleifera ethanolic leaves extract and ascorbic acid.

the reducing power potential of $M$. oleifera leaves extract and ascorbic acid. In addition, the hydrogen peroxide scavenging potential of the extract increased with increasing concentration of extract except that after 600 $\mu \mathrm{g} \mathrm{mL}^{-1} \mathrm{a}$ decline set in. The same reaction pattern was obtained with alpha-tocopherol control standard. However, the hydrogen peroxide scavenging potential of the plant extract was significantly $(p<0.05)$ higher than the control.

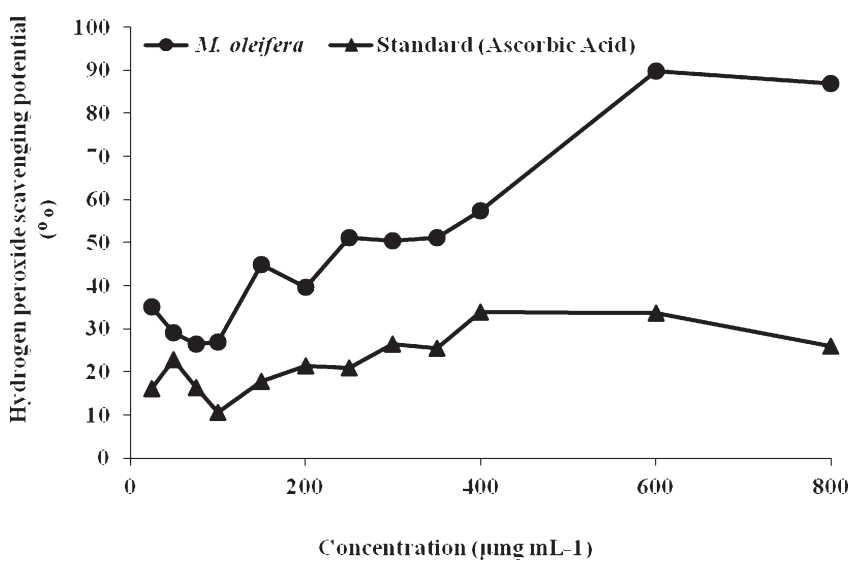

Figure 2: Hydrogen peroxide scavenging potential of $M$. oleifera ethanolic leaves extract and alpha-tocopherol.

\section{In vivo Studies}

Effect on Antioxidant enzyme, lipid peroxidation and lipid profile

There was increased SOD activity in serum of both $M$. oleifera extract and alpha-tocopherol treated animals (Fig. 3). However, SOD activity was significantly 


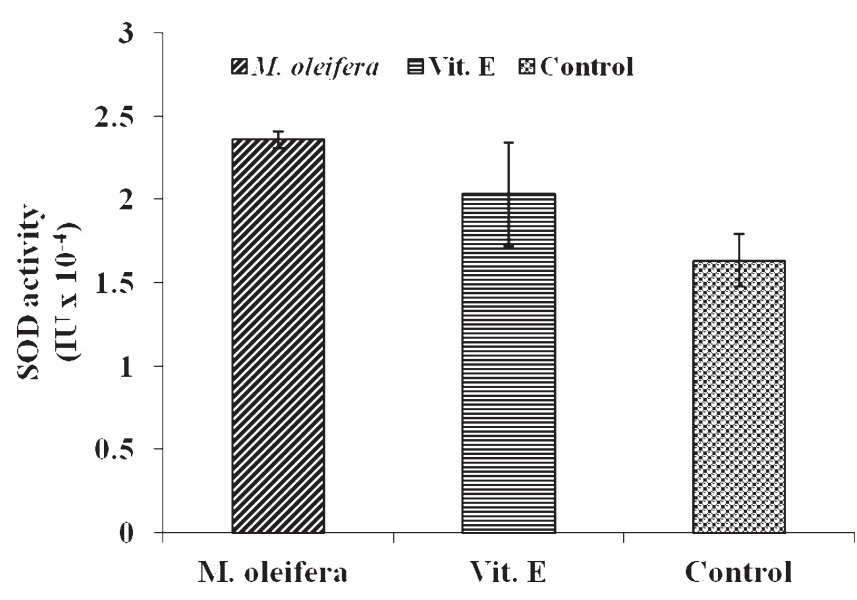

Figure 3: Superoxide dismutase activity in rats treated with Moringa oleifera ethanolic leaves extract, vitamin E, and control respectively.

$(p<0.05)$ higher in the serum of $M$. oleifera extracttreated rats than alpha-tocopherol or control-treated rats. Similarly, the leaves extract showed significant $(p<0.05)$ higher CAT activity in serum of $M$. oleifera extract-treated rats than alpha-tocopherol or controltreated rats (Fig. 4). However, there was no significant $(p<0.05)$ difference in CAT activity between alphatocopherol and control treated rats.

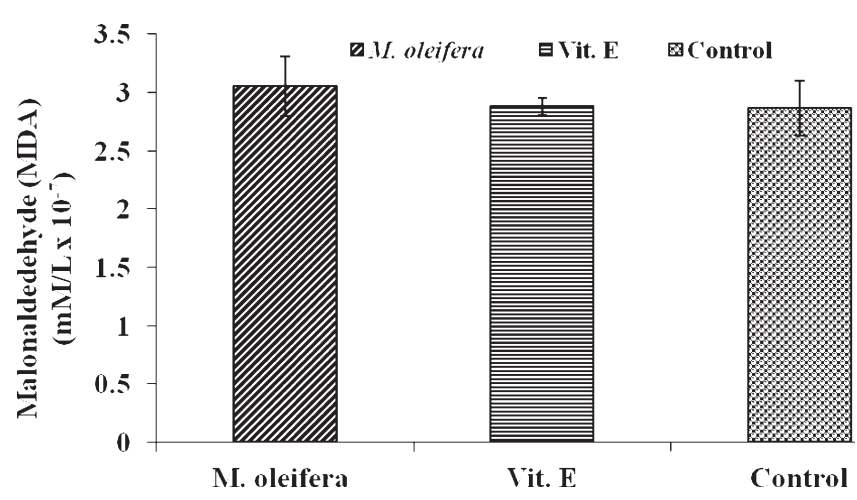

Figure 4: Catalase activity in rats treated with Moringa oleifera ethanolic leaves extract, vitamin $E$, and control respectively.

MDA serum concentration was increased in $M$. oleifera leaves extract treated animals, but this was not significantly $(p>0.05)$ different from alpha-tocopherol and control treated animals (Fig. 5).

Nevertheless, it was observed that total cholesterol was not significantly $(p<0.05)$ changed in the three groups of treated rats. However, there was an increase in LDL in the $M$. oleifera leaves extract and control treated animals compared to the alpha-
Tocopherol treated animals. Although, no significant $(p<0.05)$ difference was observed in LDL between $M$. oleifera leaves extract and control treated while significant $(p<0.05)$ difference was observed between M. oleifera leaves extract and alpha-Tocopherol treated animals likewise between alpha-Tocopherol and control treated rats. In addition, $\mathrm{HDL}$ was lowered in $M$. oleifera leaves extract and control treated rats compared to alphaTocopherol treated. Similar pattern of LDL significance $(p<0.05)$ was obtained with HDL values. Furthermore, there was no significant $(p<0.05)$ difference in VLDL obtained between $M$. oleifera leaves extract and alphaTocopherol treated, also between groups treated with alpha-Tocopherol and control respectively. However, significant $(p<0.05)$ difference in VLDL obtained was

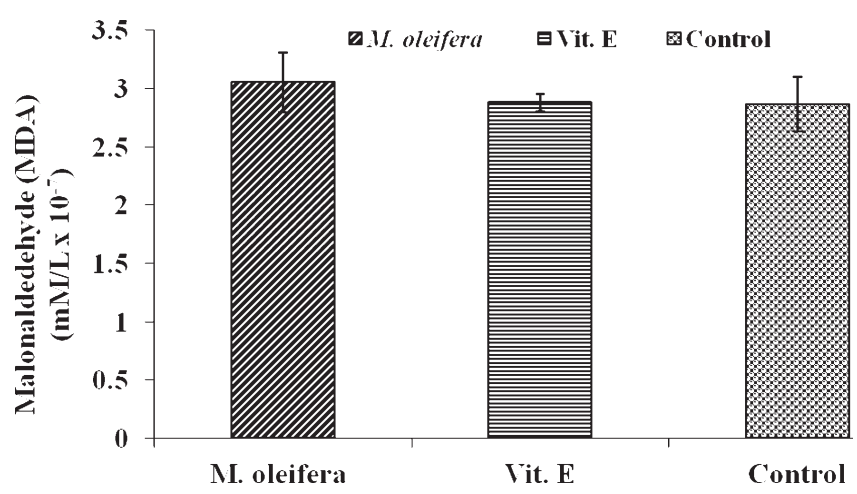

Figure 5: Concentration of malonylaldehyde $\left(m \mathrm{~L} \mathrm{~L}^{-1}\right)$ in rats treated with Moringa oleifera ethanolic leaves extract, vitamin E, and control respectively.

observed between $M$. oleifera leaves extract and control treated rats. Similar pattern of VLDL significance $(p<0.05)$ was obtained with TAG values wherein TAG was lowered by $M$. oleifera leaves extract (Table 1 ).

Table 1: Lipid Profile $\left(\mathrm{mg} \mathrm{dL}^{-1}\right)$ of rats treated with $M$. oleifera, vitamin $\mathrm{E}$ and control respectively.

\begin{tabular}{lccc}
\hline Lipid & M. oleifera & Vitamin E & Control \\
\hline TC & $77.44 \pm 6.18$ & $75.55 \pm 9.66$ & $73.19 \pm 12.78$ \\
LDL & $8.58 \pm 7.33^{\mathrm{a}}$ & $0.00^{\mathrm{b}}$ & $0.50 \pm 7.49^{\mathrm{a}}$ \\
HDL & $45.29 \pm 2.25^{\mathrm{a}}$ & $68.04 \pm 6.23^{\mathrm{b}}$ & $44.08 \pm 6.23^{\mathrm{a}}$ \\
VLDL & $23.57 \pm 1.62^{\mathrm{a}}$ & $25.38 \pm 2.86^{\mathrm{a}, \mathrm{b}}$ & $28.69 \pm 3.82^{\mathrm{b}}$ \\
TAG & $117.87 \pm 8.10^{\mathrm{a}}$ & $126.90 \pm 14.30^{\mathrm{ab}}$ & $143.45 \pm 19.14^{\mathrm{b}}$ \\
\hline
\end{tabular}

Values with dissimilar letter $(a, b$ and $c)$ are significantly $(p<0.05)$ different from each other with respect to the parameter investigated.

\section{Discussion}

The need to address the health challenges faced in modern times, particularly with regard to chronic diseases; which is recording greater incidences gave the impetus for the study. This has presented a critical 
need to finding solution for their management using plants (medicinal, herbs, foods and spices), quite abundant in the locality.

From the results of the present study, total phenols, antioxidant capacity, reducing power potential and hydrogen peroxide scavenging potential of the $M$. oleifera ethanolic leaves extract suggest that the extract has antioxidant property which supports reports that plants have strong antioxidant properties [21].

The total antioxidant capacity of the extract which was appreciable, points to the electron donating and reductive ability of the extract. This result suggests that the extract may act as radical chain terminator and transforms free radical species to stable non-reactive products [22]. Furthermore, the hydrogen peroxide scavenging potential of $M$. oleifera ethanolic leaves extract which was higher than that of ascorbic acid, indicates that the extract may be able to protect cells from oxidative damage particularly DNA breakage occasioned by exposure to toxic hydrogen peroxide [23].

It is evident from the results that $M$. oleifera ethanolic leaves extract had an effect on serum enzymatic antioxidants and lipid parameters in test rats. The elevated activity of superoxide dismutase (SOD) and catalase (CAT), may suggest an induction of the enzymes by the extract in the rats. SOD and CAT are both inducible enzymes whose production can be stimulated. Earlier reports supports this finding that SOD and CAT can be induced in animals as was observed with black rice extract [24], and ethyl acetate fraction of Globimetula branuii leaf-extract [25]. Increased activity of the enzymes could mean enhanced antioxidative capacity of the animals [22]. The antioxidant enzyme SOD is the first line of defense against reactive oxygen species, converting them to toxic $\mathrm{H}_{2} \mathrm{O}_{2}$, in living systems. Catalase, further carries out the detoxification of $\mathrm{H}_{2} \mathrm{O}_{2}$ into molecular oxygen and water.

However, high vitamin C content in the leaves of M. oleifera has been reported [26]. Vitamin C can act as a pro-oxidant as well as an antioxidant. It could therefore be suggested that vitamin $\mathrm{C}$ may have played prooxidant role in the observed induction of antioxidant enzymes as well as the observed increase in MDA level in the $M$. oleifera ethanolic leaves treated rats. This is supported by previous studies that oxidants react directly with cellular macromolecules [21] oxidizing them [23]. Moreover, the increased MDA levels in the $M$. oleifera treated rats may be accounted for by the high vitamin $C$ and/or iron content of the leaves [26, 29]. Iron, which though maintains proper cell function, has been reported to act as pro-oxidant in vivo when administered at high doses [30]. However, it is worthy to note that the increased MDA level in the $M$. oleifera treated rats may suggest lipid peroxidation even though it was not significant $(p>$ $0.05)$ compared to the other groups. Nevertheless, future studies could adjust the dose of the plant extract to eliminate the peroxidation effect.

Furthermore, lipids have been implicated in the pathogenesis of inflammatory diseases, such as rheumatoid arthritis and cardiovascular diseases [27]; therefore, M. oleifera leaves extract which had lipid lowering effect particularly of triacylglycerides and VLDL, is an encouraging one. In addition, this result is in agreement with Aattar, [28] who found that several herbs reduce high concentrations of blood lipids.

The findings of this study reflects the beneficial effects of $M$. oleifera ethanolic leaves extract towards contributing to maintaining good health particularly in protection from coronary heart diseases, cancer and aging which have been linked to reactive oxygen species. Moreover, the use of plants are gaining wide acceptance among scientists, nutritionist, food manufacturers and health givers in healthcare delivery programmes. These groups of professionals are moving towards functional foods with specific health benefits [21].

\section{Conclusion}

In this study, M. oleifera leaves extract exhibited a strengthening effect on the antioxidant capacity of the test animals. The plant extract also showed lipid lowering ability and revealed that it may be effective in management of chronic diseases with etiology in oxidative stress. The possible changes that treatment with $M$. oleifera ethanolic leaves extract might have on serum lipids was highlighted in this study. Although result from animal studies cannot definitely be extrapolated directly to humans, further studies need be done on standardization of dosage in order minimize any negative side effect.

\section{References}

1. Ara N, Rashid M, Amrad MS. Comparison of Moringa oleifera Leaves Extract with Atenolol on Serum triglyceride, Serum Cholesterol, Blood glucose, heart weight, body weight in Adrenaline Induced Rats. Saudi J Biol Sci. 2008;15:253258. 
2. Tsao R. Chemistry and Biochemistry of Dietary Polyphenols. Nutrients. 2010;2:1231-1246.

3. Blokhina O, Virolainen E, Fagerstedt K. Antioxidants, oxidative damage and oxygen deprivation stress: a review. Annals of Botany. 2003;91:179-194.

4. Pari L, KaramaæM, Kosiñska A, Rybarczyk A, Amarowicz R. Antioxidant activity of the crude extracts of drumstick tree (Moringa oleifera Lam.) and sweet Broomweed (Scoparia dulcis I.) Leaves. Pol J Food Nutr Sci. 2007;57: 203-208.

5. Middleton E, Kandaaswami C, Theoharides TC. The Effects of Plant Flavonoids on Mammalian Cells: Implications for Inflammation, Heart Disease, and Cancer. Pharm Rev. 2000; 52:673-751.

6. Anwar F, Latif, S, Ashraf M, Gilani, AH. Moringa Oleifera: A food Plant with Multiple Medicinal Uses. Phytother Res. 2007;21:17-25.

7. Oluduro AO, Aderiye BI. Effect of Moringa oleifera seed extract on vital organs and tissue enzyme activities of male albino rats. Afr J Microbiol Res. 2009;3:537-540.

8. Ajibade TO, Olayemi FO, Arowolo ROA. The haematological and biochemical effects of methanol extract of the seeds of Moringa oleifera in rats. J Med Plants Res. 2012;6:615-621.

9. Fulgie LJ. The miracle tree: Moringa oleifera, natural nutrition for the tropics. CWS. New York, 1999:4-6.

10. Khanahmadi $\mathrm{M}$, Rezazadeh $\mathrm{SH}$, Taran $\mathrm{M}$. In vitro Antimicrobial and Antioxidant Properties of Smyrnium cordifolium Boiss (Umberlliferae) Extract. Asian J Plant Sci. 2010;9:99-103.

11. Nile SH, Khobragade CN. Antioxidant activity and flavonoid derivatives of Plumbago zeylanica. J Nat Products. 2010;3:130133.

12. Nabasree D, Bratati D. Antioxidant activity of some leafy vegetables of India: A comparative study. Food Chem. 2007;101:471-474.

13. Adesegun SA, Elechi NA, Coker HAB. Antioxidant activities of methanolic extract of Sapium elliticum. Pak J Biol Sci. 2008;11:453-457.

14. Oktay M, Gulcin I, Kufrevioglu OI. Determination of in vitro antioxidant activity of fennel (Foeniculum vulgare) seed extracts. Food Sci Technol. 2003;36:263-271.

15. Igbeneghu OA, Iwalewa EO, Lamikanra A. A study of the in vivo activity of the leaf extract of Alchornea cordifolia against multiple antibiotic resistant $S$. aures isolate in mice. Phytother Res. 2007;21:67-71.

16. Kontush A, Finckh B, Karten B, Kohlschiitter A, Beisiegel $U$. Antioxidant and rooxidant activity of alpha-tocopherol in human plasma and low density lipoprotein. Lipid Res. 1996;37:1436-1448.

17. Ogbunugafor H, Sofidiya O, Okpuzor J, et al. .Effect of Extracts of Hymenocardia acida Tul (Hymenocardiaceae) on Rats. J Am Sci. 2010;6:143-146.

18. Usoh IF, Akpan EJ, Etim EO, Farombi EO. Antioxidant actions of dried flower extracts of Hibiscus sabdariffa. Pakistan J Nutr. 2005;4:135-141.

19. Aebi H. Catalase in vitro. Methods in Enzymology. 1984; 105:121-126.

20. Tietz NW. A textbook on clinical chemistry. Ed 4. W.B Sauders. Philadelphia, 1986:280-282.

21. Kähkönen MP, Hopia AI, Vuorela HJ, Rauha JP, Pihlaja K, Kujala TS, Heinonen M. Antioxidant activity of plant extracts containing phenolic compounds. J Agric Food Chem. 1999;47(10):3954-62.

22. Lobo VC, Phatak A, Chandra N. Antioxidant and Free Radical Scavenging Activity of Hygrophila schulli (Buch.-Ham.) Almeida and Almeida Seeds. Adv Biores. 2010;1:72-78.

23. Aherne SA, Kerry JP, O'Brien MN. Effects of plant extracts on antioxidant status and oxidant-induced stress in Caco-2 cells. Br J Nutr. 2007;97:321-328

24. Chiang AN, Wu HL, Yen HI, et al. Antioxidant effects of black rice extract through the induction of superoxide dismutase and catalase activities. Lipids. 2006;41:797-803.

25. Okpuzor J, Ogbunugafor H, Kareem GK. Antioxidative properties of ethyl acetate fraction of Globimetula branuii in normal rats. J Biol Sci. 2009;9:470-475.

26. Lockett CT, Calvert CC, Grivetti LE. Energy and micronutrient composition of dietary and medicinal wild plants consumed during drought. Study of rural Fulani, northeastern Nigeria. Int J Food Sci Nutr. 2000;51:195-208.

27. Darlington LG, Stone TW. Antioxidants and fatty acids in the amelioration of rheumatoid arthiritis and related disorders. British J Nutr. 2001;85:261-269.

28. Aattar AA. Comparative Physiological Study on the Effect of Rosemary, Tarragon and Bay Leaves Extract on Serum Lipid Profile of Quail, Coturnix coturnix. Saudi J Biol Sci. 2006;13:198.

29. Barminas JT, Charles M, Emmanuel D. Mineral composition of non-conventional leafy vegetables. Plant Foods Hum Nutr. 1998;53:29-36.

30. Lee D, Anderson KE, Harmck LJ, et al. Heme Iron, Zinc, Alcohol Consumption, and Colon Cancer: Iowa Women's Health Study. JNCI J Natl Cancer Inst. 2004;96: 403-407. 